\title{
Teoria Estrita e Teoria Limitada da Culpabilidade
}

\author{
Maicon Fabrício Rocha ${ }^{1}$
}

\section{Resumo}

\begin{abstract}
A Teoria Finalista da Ação e a Teoria Normativa Pura da Culpabilidade deslocaram o dolo da culpabilidade para a conduta, como elemento subjetivo do tipo, permanecendo na culpabilidade sua antinormatividade, sob a forma de potencial consciência da ilicitude. Diversos problemas foram solucionados com essas novas construções, tanto de ordem prática quanto de ordem teórica, surgindo, a partir de então, a diferença entre erro de tipo e erro de proibição. Dentro dessa nova perspectiva de culpabilidade surge a Teoria Limitada da Culpabilidade, divergindo quando ao tratamento dispensado ao erro que recai sobre os pressupostos fáticos de uma causa de justificação, entendendo que os efeitos, nesse caso, excluiriam o dolo, por oposição à Teoria Estrita que defende a exclusão da culpabilidade, no caso de erro inevitável, ou a punição por dolo com pena diminuída, no caso de erro evitável. Os argumentos da Teoria Limitada são mais de ordem prática, como a questão da justiça ou injustiça de ser dado o mesmo tratamento a todas as espécies de erro de proibição, do que de ordem propriamente teórica, fazendo surgir, assim, diversos problemas na construção dogmática da culpabilidade. Essa tensão existente entre uma dogmática bem construída e a necessidade de incorporação de critérios político-criminais pelo direito penal mostra-se, de alguma forma, sempre presente no direito e não constitui um erro, mas um acerto, necessário para que não se afaste do homem como centro e como fim do direito e de toda atividade estatal, devendo, contudo, ser tomadas as devidas cautelas para que não se aproxime demasiadamente dos extremos, pois a cegueira positivista e dogmática já se mostraram tão incompatíveis para um estado democrático de direito quanto a dominação política e ideológica sobre a máquina judicial.
\end{abstract}

Palavras Chave: Culpabilidade; Teoria Estrita; Teoria Limitada; Erro; Dogmática; Política Criminal; Estado.

\section{Introdução: o Finalismo e a teoria normativa pura da culpabilidade}

Nas teorias da culpabilidade, com a estrutura finalista do delito preconizada por Hans Welzel, sabe-se que o dolo foi deslocado da culpabilidade para a conduta, bem como que foi separado, na mesma oportunidade, de sua antinormatividade, ou seja, da consciência da ilicitude, permanecendo esta na culpabilidade como elemento autônomo (agora sob a forma de potencial consciência).

1 Acadêmico do 5o Ano de Direito da Universidade Estadual de Londrina. 
A conseqüência principal dessas alterações foi solucionar problemas tanto de ordem prática (como as lacunas de punibilidade, no caso, por exemplo, do criminoso habitual, que por não ter, eventualmente, a real consciência da ilicitude de sua conduta tinha o dolo excluído de acordo com as teorias do dolo, na sistemática das Teorias Psicológica e Psicológica-Normativa da Culpabilidade), quanto de ordem ontológica (como a conduta desprovida de finalidade, fortemente combatida por Welzel com o advento do Finalismo), quanto de ordem dogmática (o tratamento do erro de tipo e do erro de proibição eram idênticos, excluindo sempre o dolo, seja por erro sobre os elementos constitutivos do tipo penal, seja por erro sobre a real consciência da ilicitude, até então tida como elemento componente do dolo normativo).

Assim, com o advento do Finalismo e da Teoria Normativa Pura da Culpabilidade, quando o erro recaísse sobre a ilicitude da conduta, não mais teria o condão de excluir o dolo, mas de excluir a culpabilidade, se inevitável, ou de diminuir a pena, se evitável. O dolo, pois, permaneceria intacto. A partir da adoção dessa nova sistemática é que surgiram divergências que resultaram na construção das Teorias Estrita e Limitada da Culpabilidade, objeto do presente estudo.

\section{Teoria Estrita da Culpabilidade x Teoria Limitada da Culpabilidade}

A princípio, com a posteriormente denominada Teoria Estrita da Culpabilidade, considerou-se que todo e qualquer erro sobre a ilicitude conduziria inevitavelmente à exclusão da culpabilidade, se inevitável, ou, caso evitável, à punição com pena atenuada, mas sempre a título de dolo que, segundo essa perspectiva, permaneceria, de qualquer forma, intacto. Esse resultado seria o mesmo para toda e qualquer situação de erro sobre a ilicitude, quer recaísse sobre a proibição direta (erro de proibição direto) ou recaísse sobre uma causa que, se existisse, tornaria lícita a conduta, no caso das descriminantes putativas (erro de proibição indireto). Desse modo, não havia diferença no tratamento dado ao erro de proibição direto e ao erro de proibição indireto, ambos excluindo a culpabilidade, se inevitável ou diminuindo a pena, se evitável.

Nesse sentido, explica Cirino dos Santos: 


\begin{abstract}
A teoria rigorosa da culpabilidade, desenvolvida por WELZEL e predominante entre os finalistas, atribui as mesmas conseqüências a todas a modalidades de erro de proibição: o erro de proibição inevitável exclui a reprovação de culpabilidade; o erro de proibição evitável reduz a reprovação da culpabilidade, na medida da evitabilidade do erro - equiparando o erro sobre a realidade ao erro sobre a juridicidade do fato. ${ }^{2}$ (grifo do autor)
\end{abstract}

Algumas críticas surgiram, no entanto, no tratamento dado às descriminantes putativas (erro de proibição indireto), entendendo que quando o erro recaísse sobre situações de fato de uma causa de justificação não poderiam ter o mesmo tratamento das hipóteses em que o erro recaísse sobre os limites ou as permissões dessa mesma causa de justificação. Nesses casos, segundo essas críticas, os efeitos do erro deveriam equiparar-se aos efeitos do erro de tipo (em que pese não se tratar de erro de tipo). Surgiu, assim, a denominada Teoria Limitada da Culpabilidade.

De acordo com essa nova teoria, nos casos de erro de proibição direto, como no clássico exemplo do jovem holandês que chega ao Brasil portando canabis sativa por pensar que, tal como na Holanda, referido entorpecente não é ilegal nesse país, a Teoria Estrita estava correta. Do mesmo modo, estava correta também no caso de o erro recair sobre os limites permissivos (juridicidade do fato) de uma causa de justificação (como a injusta agressão da legítima defesa). Nesses casos, entendia correta a exclusão da culpabilidade se inevitável ou a punição com pena atenuada, se evitável.

O problema e o equívoco da Teoria Estrita ocorriam, segundo os partidários da Teoria Limitada, quando o erro recaísse sobre os pressupostos fáticos de uma causa de justificação (a existência da agressão na legítima defesa, por exemplo), pois, nesses casos, o efeito não poderia ser a exclusão da culpabilidade, mas sim do dolo.

Assim, o tratamento do erro sobre a ilicitude, segundo a Teoria Limitada, é classificado da seguinte maneira: a) erro de proibição direto: é o que tem por objeto a norma considerada do ponto de vista da existência, validade e eficácia, e exclui a reprovação de culpabilidade; b) erro de permissão ou erro de proibição indireto: é o erro que recai sobre uma causa de justificação, tendo por objeto os limites jurídicos dessa causa, ou a existência de uma causa de justificação não prevista em lei, e exclui a reprovação de culpabilidade, nos mesmos moldes do erro de proibição direto; c) o erro de tipo permissivo: tem por objeto os

2 SANTOS, Juarez Cirino dos. A Moderna Teoria do Fato Punível. Rio de Janeiro: Revan. 2. ed, 2002, p. 195196. 
pressupostos objetivos de justificação legal, existe como errônea representação da situação justificante, incidindo sobre a verdade do fato, e exclui o dolo (igual a um erro de tipo). ${ }^{3}$

Visível a diferença de tratamento, pois para a Teoria Estrita não há essa variante do erro de tipo permissivo, sendo este tratado como erro de proibição indireto, com a conseqüência de excluir a culpabilidade, se inevitável, e não o dolo. Consigne-se que, na prática, a diferença aparece somente no que tange ao erro vencível (que será punido com culpa ou dolo com pena reduzida, dependendo da teoria adotada), pois sendo o erro invencível, em qualquer caso, seja por ausência de dolo e culpa ou por ausência de culpabilidade, será o réu necessariamente absolvido. Nesse sentido, Luis Flavio Gomes:

Percebe-se que a distinção prática entre o erro de proibição indireto e o erro de tipo permissivo reside na consideração do erro vencível: o primeiro implica a punição do agente pela sanção do crime doloso com a possibilidade de se reduzir a pena ( $C P$, art. 21, parte final), enquanto o segundo implica a punição do agente pela sanção do crime culposo (culpabilidade negligente), se previsto em lei (CP, art. $20, \S 1$ o, parte final). ${ }^{4}$ (grifo do autor)

Assim, diferenciando as teorias, bem explica Wessels:

A Teoria Extremada da culpabilidade, representada preponderantemente pelos finalistas, vê todo erro sobre a antijuridicidade do fato como erro de proibição [...]. Não questiona, portanto, se o autor tinha a sua ação, em geral, como não proibida ou se, em conseqüência de um erro sobre a subsistência, espécie ou extensão de uma causa justificante tenha chegado só de modo indireto à opinião de que sua conduta era permitida. ${ }^{5}$

Nas palavras de Cristiano Rodrigues:

Percebe-se que ao mesmo tempo em que não se questiona o mérito da teoria Extremada da Culpabilidade de tratar como erro de proibição o erro quanto à consciência da ilicitude, também fica evidente que exatamente neste ponto reside seu principal problema, já que há diferentes formas de se constatar a ausência de conhecimento da antijuridicidade de uma conduta por seu autor, e abordar todas elas sobre o mesmo prisma não poderia resultar em outra coisa que não problemas práticos e principalmente criticas por parte da doutrina. ${ }^{6}$

SANTOS, 2002. p. 196.

4 GOMES, Luis Flávio. Erro de Tipo e Erro de Proibição. Série: as ciências criminais do século XXI, vol.3. 5. ed. São Paulo: Revista dos Tribunais, 2001, p. 186.

5 WESSELS apud RODRIGUES, Cristiano. Teorias da Culpabilidade. Rio de Janeiro: Lúmen Júris, 2004, p. 100.

6 RODRIGUES, Cristiano, 2004, p. 101. 
Justificam os adeptos da Teoria Limitada que, nos casos em que o erro recai sobre os pressupostos de fato de uma causa de justificação (o denominado erro de tipo permissivo), os efeitos devem ser equiparados ao erro de tipo porque o "agente desejava agir de acordo com o ordenamento jurídico". 7 (grifos nossos)

Do mesmo modo, justifica Luis Flavio Gomes, citando Jescheck, que a razão do privilégio que isso supõe para o erro de tipo permissivo em comparação com os casos de erro de proibição indireto, reside, por um lado, na diminuição do desvalor da ação, porque o autor acredita atuar justificadamente, crença que neste caso se acha referida a uma causa de justificação admitida (o autor acredita atuar juridicamente no sentido do direito vigente). Por outro lado, também o conteúdo da culpabilidade própria do fato se reduz claramente, pois a motivação que conduziu à formação do dolo não se baseia em uma falta de atitude interna favorável ao direito, senão em um exame descuidado da situação: ${ }^{8}$

\begin{abstract}
Se o autor acredita equivocadamente que concorrem os pressupostos de uma causa de justificação reconhecida, não falta o afastamento com respeito às representações valorativas da comunidade jurídica característica do delito doloso. A punição com apoio ao tipo doloso não parece justificada, porque o dolo se formou de forma significativamente distinta daquela que tem lugar nas hipóteses típicas de culpabilidade dolosa. ${ }^{9}$
\end{abstract}

Nesse sentido, Juarez Cirino dos Santos justifica, também, magistralmente, o porquê da diferença de tratamento adotada pela Teoria Limitada:

A equiparação do erro de tipo permissivo ao erro de tipo se baseia no argumento de que o autor quer agir conforme a norma jurídica - e, nessa medida, a representação do autor coincide com a representação do legislador, ou com o direito objetivo existente -, mas erra sobre a verdade do fato: a representação da existência de situação justificante exclui o dolo, como decisão de comportamento proibido fundada no conhecimento da existência das circunstâncias do tipo legal e inexistência de circunstancias justificantes, cuja errônea admissão significa que o autor não sabe o que faz - ao contrário do erro de permissão, em que o autor sabe o que faz. ${ }^{10}$ (grifo do autor)

E, continua:

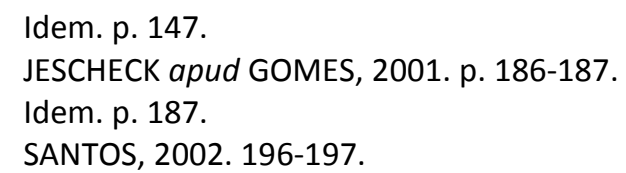


Esse tratamento diferencial do erro de proibição é explicado por critérios objetivos de valoração do comportamento: a) se o comportamento real é orientado por critérios iguais aos do legislador, os defeitos de representação do autor tem por objeto ou a situação típica (erro de tipo) ou a situação justificante (erro de tipo permissivo): ambas hipóteses excluem o dolo e admitem a possibilidade de punição por imprudência; b) se o comportamento real é orientado por critérios desiguais aos do legislador, os defeitos de representação do autor somente podem ter por objeto a valoração jurídica geral do fato (erro de proibição), com o efeito de excluir ou de reduzir a culpabilidade conforme a natureza inevitável ou evitável do erro. ${ }^{11}$ (grifo do autor)

Ou ainda, nas das palavras de Munhoz Neto:

No caso do erro de fato, o autor seria em si fiel ao direito, querendo observar a lei, cujas exigências só não cumpre por desconhecer a realidade. Coisa diversa sucederia na hipótese de erro de valoração, pelo qual o agente considera seu procedimento como justo, por uma representação viciosa no âmbito do dever jurídico. Neste caso, estaria ele em proximidade muito maior de conhecer a infração do direito, merecendo, portanto, a pena correspondente ao atuar doloso, que só poderia ser atenuada. ${ }^{12}$

Em verdade, observa-se que o privilégio (note-se que este consiste, entre outros, principalmente nos aspectos processuais penais consistentes no tratamento privilegiado de delitos culposos em detrimento de delitos dolosos, por exemplo, art. 77, I, CP, art. 89, parte final da Lei 9.099/95, artigo 313 CPP, art. 313, III, CPP, etc.) do tratamento do erro de tipo permissivo se funda no fato de o erro recair sobre situações de "fato" (existência da agressão) e não de "direito" (injustiça - elemento jurídico - da agressão), conforme se denota claramente, inclusive, das já citadas palavras de Cirino dos Santos:

A teoria rigorosa da culpabilidade, desenvolvida por WELZEL e predominante entre os finalistas, atribui as mesmas conseqüências a todas a modalidades de erro de proibição: [...] - equiparando o erro sobre a realidade ao erro sobre a juridicidade do fato. ${ }^{13}$ (grifo nosso)

O real fundamento parece guardar íntima relação com a antiga dicotomia erro de fato/erro de direito, trazendo consigo a velha repulsa, talvez até inconsciente, por parte da doutrina e do ordenamento, à aceitação de escusas baseadas em erros de direito, ainda em

$\begin{array}{ll}11 & \text { Ibidem. } \\ 12 & \text { MUNHOZ NETO apud GOMES, 2001. p. } 187 . \\ 13 & \text { SANTOS, 2002. p. 195-196. }\end{array}$ 
obediência ao velho princípio do "ignorantia legis neminem excusat", procurando privilegiar o "erro de fato" em detrimento do "erro de direito".

De outra banda, é certo também, que não está isenta de críticas essa nova formulação trazida pela Teoria Limitada da Culpabilidade, que, para solucionar problemas de ordem prática (pois entendiam injusta a igualdade de tratamento) e justificar um tratamento diferenciado quando o erro recai sobre a juridicidade ou realidade de algum fato, acabou por desenvolver uma complicada construção dogmática que, em verdade, traz consigo um grande e insuperável problema, conforme a seguir demonstrado.

Como já analisado, a Teoria Limitada trouxe uma nova espécie de erro para a dogmática jurídico-penal, o erro de tipo permissivo, que, em verdade, como dizem alguns autores, trata-se de erro 'sui generis', pois não pode ser classificado como erro de tipo, por não recair sobre os elementos do tipo, e não pode ser classificado como erro de proibição, pois se o fosse seus efeitos deveriam ser os mesmos dos outros erros de proibição. Seria uma espécie intermediária: um erro de proibição, por recair sobre a antijuridicidade, mas com efeitos de um erro de tipo, por excluir o dolo.

A exclusão do dolo é justamente onde reside o cerne de toda a crítica que se faz à Teoria Limitada, pois não é concebível que se admita essa exclusão quando, em verdade, continuam presentes os elementos que o constituem, quais sejam, a representação ou conhecimento dos elementos que constituem o tipo penal e a vontade de seu resultado.

De fato, verifica-se que o sujeito que alveja um desafeto, quer para lhe ceifar a vida, quer para se defender, independentemente de estar realmente se defendendo ou não, conhece os elementos do tipo (sabe que se trata de um ser humano, sabe que o resultado será a morte, etc.) e tem vontade desse resultado, o que torna forçoso admitir que está presente o dolo, que só seria excluído se o erro recaísse sobre um desses elementos intelectivos do tipo (caso de erro de tipo propriamente dito).

Zaffaroni e Pierangeli, criticando a Teoria Limitada, asseveram:

Esta teoria encerra a mesma ficção do que aquela que localiza a compreensão da antijuridicidade no dolo: para ela, aquele que, agindo na crença de que se encontra numa situação de legítima defesa, desfere cinco tiros para matar outro, atua sem dolo. $^{14}$

14 ZAFFARONI, Eugenio Raul; PIERANGELI, José Henrique. Manual de Direito Penal Brasileiro - parte geral. São Paulo:Revista dos Tribunais. 4. ed., 2002, p. 618. 
Se o erro recai sobre uma causa que se existisse tornaria a ação legítima, independentemente de ser um pressuposto fático ou normativo, o dolo permanece inabalado, porque o erro não recaiu sobre nenhum elemento intelectivo que o constitui, mas sobre elemento que constituiria uma causa de justificação. Tanto é certo esse raciocínio que, se não houvesse agido em erro e realmente existisse a causa que tornaria a ação legítima, ainda assim o dolo permaneceria intacto excluindo-se apenas a ilicitude da conduta.

Ainda, seguindo um raciocínio lógico: a inexistência de um elemento do tipo torna a conduta atípica; um erro invencível sobre a existência desse elemento do tipo (erro de tipo) exclui o dolo e também torna a ação atípica. Observe-se que os resultados finais são iguais: atipicidade. Já nos casos do erro de tipo permissivo acontece uma inversão lógica, pois, se a efetiva existência da causa de exclusão da antijuridicidade não tem o condão de tornar a conduta atípica (mas somente lícita), como poderia o erro sobre a existência dessa causa de justificação torná-la, além de lícita, também atípica?! E é justamente o que ocorreria se o erro fosse invencível, posto que, excluindo o dolo e a culpa, que são elementos do próprio tipo, a conclusão inafastável seria pela atipicidade da conduta. Trata-se de um absurdo lógico, pois o 'putativo' teria um efeito maior e mais privilegiado que o 'real'.

Devido a isso, é evidente que o dolo não fica, em realidade, excluído com a presença de um erro sobre uma situação fática de uma causa de justificação, nesse sentido Cristiano Rodrigues:

Não há dúvidas de que na conduta daquele que age em erro de tipo permissivo está presente o dolo de agir. Entretanto, devido a uma expressa determinação legal, pune-se na modalidade culposa a conduta praticada. ${ }^{15}$

Por outro lado, justificando essa construção que, independentemente de ser ou não a mais justa, não deixa de ser complicada e de difícil sustentação dogmática, Claus Roxin posiciona-se de maneira contrária ao exposto acima afirmando tratar-se de conduta não dolosa, argumentando que o dolo significa querer a realização de uma conduta que está proibida pelo ordenamento jurídico, sendo que, numa legítima defesa putativa, por

15 RODRIGUES, 2004. p. 110. 
exemplo, o agente não quer realizar nada ilícito, pelo contrário, acredita que se trata de algo juridicamente permitido. Logo, não atuaria com dolo. ${ }^{16}$

É certo que não merece acatamento referida argumentação, pois o autor parece confundir tipo e antijuridicidade, porque a consciência de que a conduta está proibida pelo ordenamento significa consciência da ilicitude e não do tipo. ${ }^{17}$

Francisco de Assis Toledo, por sua vez, também se posiciona de maneira contrária ao exposto acima afirmando tratar-se, realmente, de conduta culposa e não dolosa, sob o argumento de que o agente, em certas hipóteses de legítima defesa putativa, não evita, como podia e devia, a prática do crime, pelo motivo de que, de duas, uma: a) por dolo, quando o crime é de todo doloso; b) por negligência, imprudência ou imperícia, caso em que o crime só pode ser culposo, jamais com dolo atenuado, "por não ser pensável um fato único 'culposo-doloso', verdadeiro monstro mitológico". ${ }^{18}$

Em que pese o respeitável posicionamento e convincente argumento do renomado doutrinador, é certo que não afasta os argumentos anteriormente dispensados no sentido de que o dolo (vontade e representação) continua existindo. Nesse sentido, Luis Flávio Gomes, adverte que "não pode prosperar, porque, como veremos, nas descriminantes putativas o agente sempre tem consciência do que faz, isto é, ele sempre atua com dolo no tipo". 19

Além do que, a se levar em conta o argumento de Assis Toledo, terse- ia de admitir que nos outros casos de erro de proibição o efeito do erro evitável seria também a exclusão do dolo, porque em qualquer caso de erro evitável (seja erro de tipo ou erro de proibição) o sujeito age com violação de um dever de cuidado, ou seja, por impudência, negligência ou imperícia, tendo em vista que se tivesse sido mais cauteloso o erro teria sido evitado.

Desse modo, admitido que se trata de conduta dolosa e não culposa, dogmaticamente, é inadmissível que se atribua sua punição por culpa, o que só se justifica segundo critérios de política criminal (a questão da justiça ou injustiça de se dar o mesmo tratamento aos erros de fato e de direito).

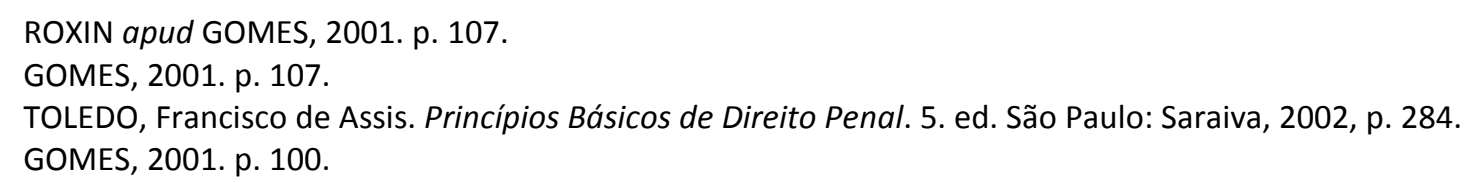


Dessa complicada construção dogmática decorre, também, outra conseqüência insuperável: a admissibilidade da tentativa culposa. De fato, como bem ilustram Zaffaroni e Pierangeli, se um sujeito, pensando encontrar-se em legítima defesa por erro evitável quanto à situação de fato, desfere tiros no seu agressor putativo, matando-o, responderia, segundo a Teoria Limitada, a título de culpa. Indaga-se: e se não conseguir mata-lo por circunstâncias alheias à sua vontade? Irrefutável que estaria configurada uma "tentativa culposa", pelo mesmo motivo que a teoria do dolo também a admite. Em suas palavras:

A crítica que se compete fazer a este entendimento é a mesma que se faz à teoria do dolo: de conformidade com ele, se teria de admitir a possibilidade de justificativa culposa. ${ }^{20}$

Do mesmo modo, explica Cristiano Rodrigues:

\begin{abstract}
No nosso entendimento o verdadeiro ponto fraco da teoria limitada da culpabilidade está no fato de que, se o autor, errando a respeito de um elemento fático integrante de uma causa de justificação, age e não obtém uma consumação material de seu ato (por exemplo, atira em um suposto agressor, em legítima defesa putativa, e erra o disparo), teria que ser punido por uma tentativa, porém, pelo fato de o erro de tipo permissivo afastar o dolo, deveria responder pela forma culposa, assim admitir-se-ia a modalidade tentada de um crime culposo, o que à primeira vista trata-se de uma inaceitável aberração jurídica gerada após complicada manobra dogmática. ${ }^{21}$
\end{abstract}

Cristiano Rodrigues, fazendo referência a Damásio de Jesus, afirma que este autor não enxerga contradição nesse caso, pois entende que há casos em que há uma tentativa dolosa, mas punida como tentativa culposa, o que, em verdade, já é em si mesmo uma contradição, parecendo "ter sido um subterfúgio, desprovido de um mínimo de responsabilidade dogmática, para tentar explicar o inexplicável”. ${ }^{22}$

Por outro lado, sob esse aspecto da admissão da tentativa culposa, embora dogmaticamente considere-se um problema insolúvel nas bases da Teoria do Delito ${ }^{23}$, Francisco de Assis Toledo, por seu turno, traz solução interessante, argumentando que, como a finalidade da conduta de desferir os tiros era defender-se e não matar, se não houve

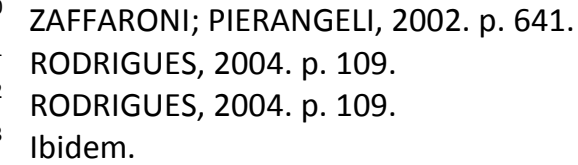


resultado naturalístico algum, não poderia haver bases para qualquer forma de responsabilização, vejamos:

O erro, no caso, é fator excludente do dolo. O agente age para defender-se, com o intuito de defender-se e não de matar. Se atua com imprudência, realizando fato culposo, em decorrência de um erro, não há como fugir-se destas hipóteses que reciprocamente se excluem: ou comete algum delito consumado (homicídio culposo ou lesões culposas) ou não comete crime algum. ${ }^{24}$

Percebe-se nesse argumento uma boa solução para a Teoria Limitada explicar a exclusão do dolo, pois, assim, o dolo ficaria excluído com base na finalidade, que seria de se defender e não de matar, o que, por outro lado, não nega o fato de que tentou matar, nem que seja para se defender, tanto que quando efetivamente há a exclusão da ilicitude pela legítima defesa o que fica excluído não é a tipicidade (pela exclusão da finalidade, conforme argumento acima) mas sim tão somente da ilicitude, o dolo continua permanecendo intacto.

Do mesmo modo, é certo que o resultado naturalístico é sempre exigido para configuração do delito culposo (que é justamente o resultado decorrente da violação de um dever de cuidado, a princípio, atípica), motivo que faz com que o argumento acima inverta lógica do instituto, partindo da premissa de que é verdadeiro justamente o que se quer demonstrar que seja verdadeiro (a existência da conduta culposa e não dolosa), ou seja, em outras palavras, tenta justificar a não responsabilização partindo do pressuposto de que a conduta é culposa, retornando, assim, ao ponto de partida que reside justamente na discussão de ser a conduta culposa ou dolosa.

Ainda, quanto à Teoria Limitada da Culpabilidade e o seu tratamento privilegiado ao erro sobre as situações de fato da causa de justificação, vale a pena consignar as críticas de Zaffaroni e Pierangeli:

Acreditamos que os esforços para justificá-la não obtiveram resultados satisfatórios porque, tão de acordo com o direito crê atuar aquele que está num erro de proibição, como aquele que atua num erro indireto, além do que ambos querem produzir um resultado típico, ignorando ser ele antijurídico. Sem embargo disso, existe uma explicação - não justificação - que, no nosso entendimento, a cada dia que passa se torna mais sinistra e manifesta: o tratamento privilegiado da 'justificação putativa' vencível é uma cobertura de lenidade e impunidade para os agentes do Estado. A grande maioria dos casos de erros vencíveis na forma de 'eximente putativas' são protagonizados pelo pessoal armado dos corpos de

24 TOLEDO, 2002. p. 306. 
segurança do Estado quando atuam contra os civis, suspeitos ou não. É óbvio que em face do texto legal, devemos respeitar o princípio da legalidade e atenuar a pena, ou prescindir dela, da forma como a lei estabelece, mas conosco fica a dúvida sobre não ser este insuportável privilégio uma violação de Direitos Humanos, pela insuficiente tutela da vida humana. ${ }^{25}$

Por fim, cabe consignar que a Teoria Limitada encerra o mesmo resultado da adoção da chamada Teoria dos Elementos Negativos do Tipo, segundo a qual o tipo seria constituído não só dos elementos objetivos, descritivos e valorativos do tipo penal propriamente dito, mas também de ausências de causa de justificação. O denominado tipo total de injusto.

Segundo essa teoria, para se ter configurada a tipicidade de uma conduta, é necessário que a conduta descrita no tipo penal não tenha sido realizada acobertada por alguma causa de justificação, ou seja, em outras palavras, a ausência de uma causa de justificação passa a ser mais um elemento do tipo penal. Ela engloba a antijuridicidade dentro da tipicidade.

Seguindo esse raciocínio, o autor que age com erro sobre uma causa de justificação (fática ou jurídica), em verdade, erra sobre um elemento do tipo, donde se admite que o dolo, nesse caso, pudesse ser excluído pelo fato de que a representação de um dos elementos do tipo - ausência da justificação - estaria viciada.

Assim, observa-se que essa teoria conduz ao mesmo resultado da Teoria Limitada, só que por fundamentos distintos. Nesse sentido, explica Juarez Cirino dos Santos:

Como esclarecimento complementar, a sugestiva teoria das características negativas do tipo - contra a qual, na verdade, não existe nenhum argumento sério - resolve o problema do erro sobre a situação justificante de modo idêntico à teoria limitada da culpabilidade, mas com fundamentos diferentes: considera os componentes do tipo legal como elementos positivos e as justificações como elementos negativos do tipo de injusto e, por conseqüência, define o erro sobre a situação justificante como erro de tipo, excludente do dolo-e, por extensão, do tipo -, se inevitável, admitindo a imprudência, se evitável. ${ }^{26}$

O resultado idêntico levou ao ponto de alguns autores enxergarem nela a sua própria origem:

25 ZAFFARONI; PIERANGELI, 2002. p. 643.

26 SANTOS, 2002. p. 197. 
Frente à teoria 'estrita' da culpabilidade surgiu outra teoria, que introduz uma complicação no esclarecimento do problema, e que é a complementação lógica da teoria dos elementos negativos do tipo ao nível da culpabilidade. Trata-se da 'teoria limitada da culpabilidade'. ${ }^{27}$

É certo, porém, que se a Teoria Estrita foi rechaçada pela Teoria Limitada pelo fato de dar o mesmo tratamento ao "erro de fato" (no sentido de erro sobre a situação fática) e ao "erro de direito" (erro sobre a juridicidade), ambos excluindo a culpabilidade, essa Teoria dos Elementos Negativos do Tipo padece do mesmo problema, só que tratando todos como erro de tipo, excluindo a tipicidade da conduta.

\section{A Teoria Complexa da Culpabilidade}

Para tentar solucionar esse problema da Teoria Limitada consistente na exclusão do dolo no erro de tipo permissivo, tem-se falado em uma Teoria Complexa da Culpabilidade, sustentada principalmente por Wessels, Jescheck e Maurach, e, no Brasil, principalmente por Luis Flávio Gomes e César Roberto Bittencourt, segundo a qual, o dolo e a culpa teriam vertentes tanto na conduta quanto na culpabilidade, vejamos os ensinamentos de Cristiano Rodrigues:

O modelo proposto por Wessels e Jescheck afirma que o fato de o dolo ser o elemento subjetivo do tipo penal não retira dele uma função dentro da culpabilidade, sendo que no tipo o dolo é a relação psíquica do autor com o mundo fático que se materializa através da realização da conduta objetivamente expressa em lei, enquanto que, na seara da culpabilidade, o dolo é portador do 'desvalor do ânimo', ou seja, contrariedade de vontade do agente em relação à ordem jurídica no momento da prática do fato. ${ }^{28}$

Quanto à questão do erro, argumentam seus partidários que, quando a Teoria Limitada fala em exclusão do dolo está se referindo ao dolo da culpabilidade e não ao dolo da conduta, pelo que, a conduta continuaria sendo dolosa (o que espancaria as críticas à Teoria Limitada), mas o dolo da culpabilidade seria excluído. Nesse sentido, é o posicionamento de Luis Flávio Gomes:

$\begin{array}{ll}27 & \text { ZAFFARONI e PIERANGELI, 2002. p. } 617 . \\ 28 & \text { RODRIGUES, 2004. p. } 157 .\end{array}$ 
[...] nas descriminantes putativas fáticas (erro de tipo permissivo, previsto no art.20, $\$ 1$ 을 do CP) o agente atua com dolo (consciência e vontade de realizar os requisitos objetivos do tipo), mas a atitude interior que dele emana (de menosprezo ou indiferença ao bem jurídico) resulta anulada em razão da convicção de que podia agir, de que estava autorizado a agir nas circunstâncias em que se encontrava. Há uma suposição errônea de uma situação justificante (crença que atua em legítima defesa, por exemplo) que anula por completo a correspondente culpabilidade que decorre do injusto típico doloso. ${ }^{29}$ (grifo nosso)

Assim, percebe-se que essa teoria, por um lado, resolve o problema do tipo permissivo da Teoria Limitada da Culpabilidade, mas, por outro lado, retorna à antiga e já superada Teoria Psicológico-Normativa da culpabilidade, caracterizando, nesse ponto, um verdadeiro retrocesso na evolução da culpabilidade normativa, além do que, como bem critica Rodrigues:

Deve-se observar este novo posicionamento doutrinário com cautela, pois não se pode impunemente, buscando pela via inversa explicar um instituto penal, qual seja, o erro de tipo permissivo, reestruturar toda a teoria da culpabilidade sem esbarrar em paradigmas teleológicos, tão pouco fechar os olhos para as conseqüências desta reformulação proposta, que indiscutivelmente abala toda a base da Teoria do Delito. ${ }^{30}$

Do mesmo modo, Muñoz Conde critica essa dupla posição:

\begin{abstract}
A teoria final da ação parece haver demonstrado que o tipo pode compreender sem violência essa característica subjetiva que se chama dolo natural, além de outras características subjetivas os chamados elementos subjetivos do injusto que a doutrina tradicional incluía também nele. Voltar a incluir estes elementos na culpabilidade parece uma complicação desnecessária e uma falta antissistemática [...]. O que não se pode fazer é querer incluir um mesmo fato em duas categorias sistemáticas distintas, pois então, para que servem as classificações e disposições sistemáticas? ${ }^{31}$
\end{abstract}

Diante disso, é de se advertir que essa moderna sistemática deve ser vista com cautela para não se transformar em mais um enigma indecifrável como ocorre com tantas outras doutrinas e teorias criadas para resolver um pequeno problema específico e que acabam trazendo consigo outra série de dificuldades ainda mais intransponíveis.

29 GOMES, 2001. p. 178.

RODRIGUES, 2004. p. 157.

31 CONDE apud GOMES, 2001. p. 174. 


\section{Conclusão}

Da análise levada a efeito, observa-se que o estudo da Culpabilidade encontra-se em constante evolução, crescendo na medida em que o homem descobre a si mesmo, sendo constantemente influenciado por novas construções doutrinárias lastreadas em critérios de política criminal que trazem para o estudo do Direito Penal soluções práticas para casos em que, a se levar em conta tão somente uma dogmática bem construída, poderiam resultar em graves injustiças e contrariedade ao senso comum da sociedade.

Essa tensão dialética que se estabelece entre uma dogmática bem construída e fundamentada de um lado e, de outro, critérios de política criminal que, por vezes, clamam pela necessidade de reprovação mesmo sem haver bases dogmáticas para tanto, e, outras vezes, clamam pela não responsabilização ou responsabilização diminuída ou privilegiada (responsabilizando-se dolo como culpa, por exemplo), como é o caso do tipo permissivo, esteve sempre presente, de alguma forma, na construção do Direito Penal e contribuiu e vem contribuindo para novas construções teóricas e novas concepções dogmáticas, que, por sua vez, tornam-se tese para outras antíteses sociais e assim sucessivamente.

No que respeita especificamente ao tema das teorias Estrita e Limitada, verifica-se essa influência no próprio argumento principal utilizado pelos defensores da Teoria Limitada no sentido de que o erro vencível sobre os pressupostos fáticos de uma causa de justificação merece punição a título de culpa porque o agente "quis agir em conformidade ao direito", entendendo que não seria justo, sensato ou razoável puni-lo por dolo tal como se faz com o que errou sobre a juridicidade do fato. Como se vê, trata-se de um argumento que se vale de razoabilidade, de critérios de justiça ou de política criminal, e não de uma construção teórica ou dogmática.

Assim, é certo que, em que pese essas influências abalarem, por vezes, uma construção teórica com bases sólidas e sem contradições, elas são, de certa forma, necessárias para que não se distancie do homem como centro e como fim do direito e de toda atividade estatal, devendo, no entanto, ser sempre muito bem dosadas para casos de real necessidade, utilizando-se de critérios de razoabilidade e proporcionalidade, cuidandose sempre para não se aproximar dos extremos, pois a cegueira positivista e dogmática já se mostrou tão incompatível para um estado democrático de direito quanto a dominação política e ideológica sobre a máquina judicial. 


\section{Referências}

BITENCOURT, Cezar Roberto; CONDE, Francisco Muñoz. Teoria Geral do Delito. São Paulo: Saraiva, 2000.

CAPEZ, Fernando. Curso de Direito Penal. 8. ed. São Paulo: Saraiva, 2005. v. 1.

CHAMON JR., Lúcio Antônio. Do Giro Finalista ao Funcionalismo Penal: embates de perspectivas dogmáticas decadentes. Porto Alegre: Sérgio Antonio Fabris, 2004.

GOMES, Luis Flávio; Erro de Tipo e Erro de Proibição. 5. ed. São Paulo: Revista dos Tribunais, 2001. (As ciências criminais do século XXI, v. 3.).

JAKOBS, Günther; Fundamentos do Direito Penal. Tradução Andrá Luís Callegari. São Paulo: Revista dos Tribunais, 2000.

JESUS, Damásio Evangelista de. Direito Penal - parte geral.. 25. ed. São Paulo: Saraiva, 2002. v. 1.

LUISI, Luiz. O Tipo Penal, a Teoria Finalista e a Nova Legislação Penal. Porto Alegre: Sergio Antonio Fabris Junior, 1987.

MIRABETE, Julio Fabbrini. Manual de Direito Penal - Parte Geral. 21. ed. São Paulo: Atlas, 2004.

NORONHA, E. Magalhães. Direito Penal - Parte Geral. 36. ed. São Paulo: Saraiva, 2001.

PRADO, Luis Régis. Curso de Direito Penal Brasileiro - parte geral. 4. ed. São Paulo: Revista dos Tribunais, 2004. v. 1.

PRADO, Luis Régis; CARVALHO, Érika Mendes de. Teorias da Imputação Objetiva do Resultado: uma aproximação crítica a seus fundamentos. São Paulo: Revista dos Tribunais, 2002.

REALE JR., Miguel. Teoria do Delito. 2. ed. São Paulo. Revista dos Tribunais, 2000.

RODRIGUES, Cristiano. Teorias da Culpabilidade. Rio de Janeiro: Lúmen Júris, 2004.

ROXIN, Claus. Política Criminal e Sistema Jurídico Penal. Tradução Luís Greco. Rio de Janeiro São Paulo: Renovar, 2002. 
SANTOS, Juarez Cirino dos. A Moderna Teoria do Fato Punível. 2. ed. Rio de Janeiro: Revan, 2002.

TAVARES, Juarez. Teoria do Injusto Penal. 3. ed. Belo Horizonte: Del Rey, 2003.

TEOTONIO, Luis Augusto Freire. Culpabilidade: concepções e modernas tendências internacionais e nacionais. Editora Minelli, 2002.

TOLEDO, Francisco de Assis. Princípios Básicos de Direito Penal. 5. ed. São Paulo: Saraiva, 2002.

ZAFFARONI, Eugenio Raul; PIERANGELI, José Henrique. Manual de Direito Penal Brasileiroparte geral. 4. ed. São Paulo: Revista dos Tribunais, 2002.

WELZEL, Hans. O Novo Sistema Jurídico Penal - uma introdução à doutrina da ação finalista. Tradução de Luis Régis Prado: Revista dos Tribunais, 2001. 
ReVista de Direito Público, LondRINA, V. 1, N. 1, P. 245-262, JAN./ABR. 2006. 